\title{
Edukasi Kader dalam Upaya Pencegahan dan Penanggulangan Stunting di Kecamatan Mondokan Kabupaten Sragen
}

\author{
Anik Lestari ${ }^{1,3 *}$ dan Diffah Hanim ${ }^{2,3}$ \\ ${ }^{1}$ Program Studi Kedokteran, Fakultas Kedokteran, Universitas Sebelas Maret, Surakarta, Indonesia; ${ }^{2}$ Program \\ Studi S2 Ilmu Gizi, Pascasarjana, Universitas Sebelas Maret, Surakarta, Indonesia; ${ }^{3}$ Pusat Penelitian dan \\ Pengembangan Pangan Gizi dan Kesehatan Masyarakat, LPPM Universitas Sebelas Maret, Surakarta, Indonesia
}

Diterima: 30 Maret 2020; Disetujui: 22 April 2020

\begin{abstract}
Abstrak
Saat ini stunting menjadi fokus perhatian masalah gizi oleh pemerintah Indonesia karena tidak hanya menyebabkan kelainan fisik namun juga kognitif yaitu berupa kecerdasan yang kurang pada balita sehingga saat dewasa akan menurunkan produktivitasnya. Tujuan pengabdian masyarakat ini secara langsung untuk meningkatkan pengetahuan kelompok masyarakat tertentu (para kader gizi kesehatan) dalam hal pencegahan stunting pada balita. Dengan terjadinya proses transfer pengetahuan tersebut, diharapkan akan terjadi perubahan perilaku dari khalayak sasaran dalam menjalankan tugasnya sebagai kader yang bertugas di posyandu. Pelaksanaan pengabdian menggunakan lebih dari satu metode. Pada kesempatan pertama dilakukan metode penyuluhan kelompok dengan ceramah dan tanya jawab. Metode kedua digunakan untuk menilai apakah materi penyuluhan telah dapat dipahami oleh para peserta yaitu dengan melakukan permainan "cerdas cermat". Pelaksanaan pengabdian masyarakat berupa edukasi gizi kesehatan dengan sasaran kader PKK di wilayah Kecamatan Mondokan, Sragen telah berhasil dilaksanakan dengan baik. Para kader sangat antusias dalam mengikuti kegiatan tersebut. Hal ini dapat dilihat dari partisipasi aktif mereka dalam memberikan pertanyaan saat narasumber menyampaikan materi. Selain itu, ketika dilakukan permainan "cerdas cermat", para kader dapat menjawab pertanyaanpertanyaan terkait materi "pencegahan stunting" dengan baik. Dari 20 pertanyaan yang diberikan, para kader berhasil menjawab dengan benar sebanyak 17 pertanyaan. Kegiatan edukasi ini perlu ditindaklanjuti dengan "pelatihan" dan "pendampingan", karena jika hanya diberikan penyuluhan satu kali saja dikhawatirkan para kader belum dapat menerapkan pengetahuan barunya dengan baik.
\end{abstract}

Kata kunci: balita; edukasi; gizi seimbang; pola makan; stunting

\section{Cadre Education in Stunting Prevention and Management in Mondokan Subdistrict of Sragen}

\section{Abstract}

Nowadays stunting has become the most observed on nutrition issues by the Indonesian government because stunting does not only cause physical abnormalities but also cognitive impairment in todlers so that as adults they will have low productivity. The aim of this community service was to increase the knowledge of certain community groups (health nutrition cadres) in preventing stunting in todlers. With the process of diffusion of knowledge, it is expected that there will be improvement in behavior of the target audience in carrying out their duties as posyandu cadres. This community service agenda are implemented through two activities. By having lectures and QnA sessions. The second method namely

\footnotetext{
*Corresponding author: aniklestari@staff.uns.ac.id
}

Cite this as: Lestari, A., \& Hanim, D. (2020). Edukasi Kader dalam Upaya Pencegahan dan Penanggulangan Stunting di Kecamatan Mondokan Kabupaten Sragen. AgriHealth: Journal of Agri-food, Nutrition and Public Health, 1(1), 7-13. doi: http://dx.doi.org/10.20961/agrihealth.v1i1.41106 
"cerdas cermat" was used to assess whether the counseling material can be understood by the participants. A team answer correctly they will be given a "door prize". The implementation of community service in the form of health education targeting Posyandu cadres in Mondokan Subdistrict, Sragen has been successfully implemented. The cadres were very enthusiastic to participate in the activity. This was indicated by their active participation in asking questions during lectures. In addition, during the game "cerdas cermat" was held, cadres can successfully answer questions related to the material "prevention of stunting". This educational activity needs to be followed up by "training" and "assistance", because if it is only given lecturing once it was feared that cadres could nott apply their new knowledge well.

Keywords: balance nutrition; education; feeding practice; stunting; todler

\section{PENDAHULUAN}

Salah satu permasalahan gizi di Indonesia yang mengemuka dalam dekade ini adalah balita dengan postur pendek (stunting). Stunting disebut juga sebagai gizi kurang kronis yang menggambarkan adanya gangguan pertumbuhan tinggi badan yang berlangsung pada kurun waktu lama. Stunting menyebabkan perkembangan buruk pada balita, terganggunya fungsi kognitif, metabolisme dan penurunan keaktifan. Rendahnya Inisiasi Menyusu Dini (IMD) dan pemberian air susu ibu (ASI) eksklusif berpengaruh terhadap pertumbuhan anak. WHO (2013) menyebutkan bahwa penyebab masalah stunting salah satunya adalah penundaan IMD, tidak diterapkannya pemberian ASI eksklusif dan penyapihan ASI terlalu dini. Days State of the World's Mothers tahun 2012 menyatakan bahwa kejadian stunting dipengaruhi oleh kondisi pada masa 1000 hari kehidupan yaitu mulai dari janin berada dalam perut atau ketika wanita dalam kondisi hamil sampai anak tersebut berusia 2 tahun. Masa ini disebut dengan masa critical windows, karena terjadi perkembangan otak atau kecerdasan dan pertumbuhan badan yang cepat. Bila tidak diberikan asupan gizi cukup pada ibu hamil, tidak diberikan ASI eksklusif, dan pemberian Makanan Pendamping ASI (MP-ASI) yang kurang bergizi pada anak, maka berpotensi terjadinya stunting. IMD dan ASI eksklusif membantu bayi mendapatkan kekebalan tubuhnya sehingga dapat mengatasi infeksi. Stunting pada anak-anak di negara berkembang terjadi akibat dari kekurangan energi kronis dan penyakit infeksi. Infeksi menyebabkan terjadinya kekurangan gizi, sehingga pertumbuhan linier terhambat.

Menurut Riskesdas (2013), prevalensi stunting di Indonesia $37,2 \%$. Prevalensi ini menurun pada Riskesdas 2018 menjadi 30,8\%. Angka ini masih berada di atas cut off point dari WHO yang menetapkan batas di bawah 20\% (Mitra Pangan dan Gizi Indonesia, 2019). Menurut Riskesdas (2018) prevalensi stunting di Jawa Tengah 33,4\% sedangkan di Kabupaten Sragen prevalensinya $39,7 \%$ berarti saat ini prevalensi stunting di Kabupaten Sragen lebih tinggi dibandingkan dengan angka nasional maupun Jawa Tengah. Menurut data Dinas Kesehatan Kabupaten Sragen tahun 2019 angka kejadian stunting yang tertinggi berada di Kecamatan Mondokan (Pemerintah Kabupaten Sragen, 2019).

Status gizi khususnya status gizi anak balita merupakan salah satu indikator kualitas sumber daya manusia yang menentukan tingkat kesejahteraan masyarakat yang akan datang. Sedemikian strategisnya status gizi dalam upaya pembangunan manusia Indonesia, sehingga ditetapkan sebagai salah satu sasaran dan target Rencana Pembangunan Jangka Menengah Nasional (RPJMN) bidang Kesehatan, yaitu menurunkan prevalensi balita gizi kurang dan balita pendek/stunting dengan mengacu pada indikator kinerja kegiatan pembinaan gizi masyarakat (Kemenkes RI, 2014).

Periode emas pertumbuhan anak yaitu pada usia 0-24 bulan, karena anak mengalami pertumbuhan yang pesat. Asupan zat gizi pada masa tersebut sangat penting, sehingga perlu mendapatkan perhatian khusus. Pada masa bayi, asupan gizi yang diperoleh sangat bergantung pada pengasuhnya. Selama tahun pertama, berat badan bayi meningkat tiga kali lipat dibanding berat lahirnya dan $65 \%$ dari total pertumbuhan otak terjadi pada masa tersebut (Meadow et al., 2005).

Masalah gangguan tumbuh kembang pada bayi dan anak usia di bawah 2 tahun (baduta) merupakan masalah yang perlu ditanggulangi dengan serius. Usia di bawah dua tahun merupakan masa yang amat penting sekaligus 
masa kritis dalam proses tumbuh kembang anak baik fisik maupun kecerdasan. Kurus dan stunting pada usia sekolah akan berdampak pada performa belajar di sekolah. Ibu hamil dengan status Kurang Energi Kronis (KEK) dapat berdampak pada pertumbuhan dan kesehatan bayinya (Kemenkes RI, 2014). Menurut WHO (1986), kader adalah laki-laki atau perempuan yang dipilih oleh masyarakat dan dilatih untuk menangani masalah-masalah kesehatan baik perseorangan maupun masyarakat serta untuk bekerja dalam hubungan yang amat dekat dengan tempat pelayanan kesehatan dasar. Menurut Mantra (1997), kader adalah tenaga sukarela yang tepat untuk usaha-usaha masyarakat karena berasal dari masyarakat, sehingga mengenal masyarakat setempat, disegani dan dipercaya masyarakat sehingga saran dan petunjuknya akan didengar dan diikuti oleh masyarakat.

Berdasarkan latar belakang yang dipaparkan bahwa Kabupaten Sragen dengan prevalensi stunting 39,7\% (Riskesdas, 2018) termasuk dalam 100 daerah prioritas nasional untuk penanganan stunting. Kecamatan Mondokan merupakan wilayah dengan prevalensi stunting paling tinggi. Pengabdian ini bermaksud untuk membantu pemerintah daerah dalam mengatasi permasalahan gizi yang saat ini menjadi fokus perhatian di wilayah tersebut melalui upaya peningkatan pengetahuan dan keterampilan kader dalam mencegah stunting. Permasalahan yang mengemuka yaitu masih tingginya angka kejadian stunting di Indonesia. Hal ini membuat tim pengabdi merasa prihatin sehingga termotivasi untuk turut serta berkontribusi dalam upaya pencegahan dan penanggulangan stunting, terutama di wilayah dengan angka kejadian stunting yang masih cukup tinggi.

Pemecahan masalah yang dilakukan oleh tim pengabdi yaitu dengan mengacu pada pendekatan Promosi Kesehatan. Menurut Naidoo dan Wills (2008), pendekatan dalam Promosi Kesehatan ada lima bentuk yaitu: Pendekatan Medis (medical), Perubahan Perilaku (behaviour change), Pendidikan (educational), Pemberdayaan (empowerment), Perubahan Sosial (social change). Tim pengabdi memilih pendekatan "Pendidikan/ Edukasi" sebagai salah satu pendekatan dalam promosi kesehatan pada kegiatan pengabdian kali ini. Edukasi dipilih diantara empat pendekatan promosi kesehatan lainnya dimaksudkan sebagai langkah awal yang paling praktis, mengingat kerjasama yang dilakukan dengan pihak mitra dalam hal ini Pemerintah Kecamatan Mondokan masih dalam taraf penjajakan. Untuk kedepannya, tim pengabdi berencana melanjutkan pengabdiannya dengan pendekatan promosi kesehatan lainnya.

Sasaran edukasi adalah para kader gizi kesehatan karena mereka menempati posisi strategis dalam upaya pencegahan dan penanggulangan stunting yaitu sebagai garda terdepan yang langsung melayani ibu hamil dan balita di posyandu. Dengan terjadinya peningkatan pengetahuan para kader tentang seluk beluk stunting diharapkan mereka mempunyai persepsi yang benar tentang stunting yang berdampak pada terjadinya perubahan sikap dan perilaku mereka dalam menangani permasalahan-permasalahan gizi dan kesehatan yang mereka temukan di posyandu.

Pengetahuan yang telah mereka miliki dapat menjadi bekal dalam memberikan penyuluhan dan konseling kepada ibu balita di posyandu dalam melakukan asah, asih dan asuh terhadap putra/putrinya. Diharapkan para kader mampu melakukan transfer of knowledge terhadap ibu atau pengasuh balita yang datang ke posyandu dalam melakukan upaya pencegahan dan penanggulangan stunting. Pengabdian ini diharapkan dapat meningkatkan pengetahuan dan pemahaman kader gizi kesehatan terhadap kondisi stunting sehingga mereka memahami dan mampu menerapkan pengetahuan dan keterampilan yang diberikan dalam menjalankan tugasnya sebagai kader di posyandu balita.

Tujuan pengabdian masyarakat ini secara langsung untuk meningkatkan pengetahuan kelompok masyarakat tertentu yaitu para kader gizi kesehatan yang dalam ilmu promosi kesehatan disebut sebagai sasaran sekunder dalam hal pencegahan stunting pada balita. Dengan terjadinya proses transfer pengetahuan tersebut, diharapkan akan terjadi perubahan perilaku dari khalayak sasaran dalam menjalankan tugasnya sebagai kader posyandu. Kader merupakan salah satu role model yang keberadaannya disegani oleh masyarakat. Dengan adanya kegiatan ini diharapkan para kader gizi kesehatan lebih giat untuk melakukan transfer of knowledge kepada ibu-ibu dan pengasuh balita (sebagai sasaran primer) tentang pola makan gizi seimbang, pola hidup bersih dan sehat serta pola asuh yang baik dalam upaya pencegahan stunting sehingga dapat menurunkan angka kejadian stunting di wilayah kerjanya. 


\section{BAHAN DAN METODE}

\section{Jenis dan rancangan pengabdian masyarakat}

Desain atau rancangan pengabdian adalah riset aksi (action research) untuk menerapkan intervensi dalam bidang kesehatan yang dilakukan oleh tim pengabdi bekerjasama dengan Pemerintah Kecamatan Mondokan, Kabupaten Sragen. Dalam hal ini tim pengabdi mempunyai peran sebagai agen perubahan (agent of change). Aksi yang dilakukan oleh pengabdi adalah memberikan intervensi berupa edukasi tentang pencegahan dan penanggulangan stunting terhadap sasaran sekunder yaitu kader posyandu. Aksi tersebut dilakukan berdasarkan penelusuran pustaka dari berbagai macam hasil penelitian yang dilakukan oleh lembaga pemerintah maupun akademisi.

\section{Tempat dan waktu pelaksanaan}

Tim pengabdi melakukan kegiatannya di wilayah Kecamatan Mondokan, Kabupaten Sragen. Pengabdian masyarakat yang berupa edukasi kepada kader gizi kesehatan ini diselenggarakan pada tanggal 4 Maret 2020. Jumlah kader yang hadir ada 115 orang dari 9 desa yang ada yaitu desa Pare, Kedawung, Trombol, Tempelrejo, Sono, Sumberejo, Gemantar, Jekani, dan Jambangan. Sebagian besar kader adalah perempuan (98\%) sedangkan kader laki-laki sebesar (2\%). Kegiatan ini merupakan agenda Pengabdian Masyarakat dalam rangka peringatan Dies Natalis UNS yang ke 44.

\section{Metode serta langkah-langkah pelaksanaan}

Langkah-langkah yang diupayakan oleh tim pengabdi meliputi: Melakukan koordinasi dengan Pemerintah Kecamatan Mondokan Kabupaten Sragen untuk dapat mengumpulkan kader pada waktu dan tempat yang tepat. Bekerjasama dengan Pemerintah Kecamatan Mondokan Kabupaten Sragen untuk dapat memfasilitasi kegiatan Edukasi Kesehatan yang dilakukan oleh P4GKM, LPPM, UNS. Menyiapkan materi untuk edukasi kader dengan tema stunting, yang meliputi: pengertian/definisi, gejala/kelainan fisik yang nampak dari luar, perlunya stunting untuk menjadi perhatian pemerintah dan masyarakat, cara deteksi dini, cara pencegahan sejak masih dalam kandungan ibu, cara penanggulangan jika sudah terdeteksi stunting, penanggulangannya dengan menerapkan pola makan gizi seimbang, pola hidup bersih dan sehat serta pola asuh yang baik dan benar, materi spesifik berupa: IMD, pemberian ASI eksklusif (pada usia 0 sampai dengan 6 bulan), pemberian ASI ditambah dengan Makanan Pendamping ASI (pada usia lebih dari 6 bulan sampai dengan 2 tahun). Memberikan edukasi kepada kader dengan menggunakan lebih dari satu metode penyuluhan/komunikasi.

Metode pertama dengan menggunakan "Penyuluhan Kelompok" berupa ceramah dan tanya jawab. Dengan menggunakan komunikasi secara dua arah diharapkan peserta tidak bosan dan dapat menyimak dan berpartisipasi secara aktif dalam penyuluhan. Metode kedua dengan menggunakan permainan (game). Metode kedua digunakan untuk menilai apakah materi penyuluhan telah dapat dipahami oleh para peserta yaitu dengan melakukan permainan berupa "Cerdas Cermat" dengan cara menjawab "rebutan". Pengabdi membentuk kelompok-kelompok kecil sebagai perwakilan kader dari tiap desa. Masingmasing kelompok terdiri dari tiga orang kader. Kecamatan Mondokan, Sragen terdapat 9 desa maka terbentuk 9 regu. Jika sebuah regu dapat menjawab dengan benar maka akan diberikan "door prize". Dengan cara seperti ini diharapkan para peserta aktif mengikuti penyuluhan dan mendengarkan materi yang disampaikan oleh narasumber dengan seksama. Disela-sela penyuluhan dan permainan disajikan hiburan yang telah disediakan oleh pihak Kecamatan Mondokan berupa grup band yang mengajak segenap peserta dan tamu undangan bernyanyi bersama. Dengan demikian pada kegiatan ini para hadirin tidak hanya memperoleh ilmu namun juga dapat merasa gembira dengan permainan dan hiburan yang ada.

\section{Evaluasi serta monitoring pelaksanaan pengabdian.}

Evaluasi yang digunakan dalam kegiatan pengabdian ini berupa evaluasi proses dan evaluasi hasil. Evaluasi dalam proses pemberian edukasi dengan tema upaya pencegahan dan penanggulangan stunting dilakukan dengan cara sebagai berikut: disela-sela waktu penyampaian materi/penyuluhan kelompok, narasumber memberikan pertanyaan terkait dengan materi kepada para peserta dan sebaliknya narasumber juga memberikan kesempatan bagi para peserta untuk bertanya atau memberikan masukan sehingga dapat dinilai keaktifan dan pemahaman peserta dalam mengikuti penyuluhan. Selanjutnya dilakukan evaluasi hasil untuk edukasi kader ini dengan menggunakan cara yang menyenangkan yaitu bermain game. Narasumber menilai pengetahuan para kader melalui permainan "Cerdas 
Cermat" dengan cara menjawab "rebutan". Jika sebuah regu dapat menjawab dengan benar maka akan diberikan "door prize". Hal ini dilakukan sebagai stimulus dan penyemangat agar para peserta mau dan mampu menjawab pertanyaanpertanyaan dari narasumber sebagai tolok ukur keberhasilan edukasi tentang gizi dan kesehatan tersebut.

\section{HASIL DAN PEMBAHASAN}

Hasil pengabdian yaitu berupa fokus utama kegiatan yang dapat digunakan sebagai solusi yang diberikan kepada masyarakat di wilayah kecamatan Mondokan, Kabupaten Sragen. Hasil kegiatan dapat dibagi menjadi dua kategori yaitu yang memberikan manfaat secara langsung dan tidak langsung. Secara langsung hasilnya bermanfaat dalam peningkatan pengetahuan dan pemahaman dari para kader gizi kesehatan tentang pencegahan dan penanggulangan stunting. Secara tidak langsung, dengan bekal pengetahuan yang telah dimilikinya diharapkan para kader dapat meningkatkan sikap dan perilaku yang positif dalam upaya pencegahan dan penanggulangan stunting.

Jumlah kader yang hadir sebanyak 115 orang yang berasal dari 9 desa. Rata-rata per desa diwakili oleh 12-13 kader. Para kader sangat antusias dalam mengikuti kegiatan tersebut. Hal ini dapat dilihat dari partisipasi aktif mereka dalam menjawab beberapa pertanyaan "stimulan" yang diberikan oleh narasumber maupun sebaliknya, mereka memberikan pertanyaan bagi narasumber untuk memperoleh penjelasan yang lebih mendalam tentang hal-hal yang belum dipahami. Hampir semua regu dapat menjawab pertanyaan terkait materi yang diberikan oleh narasumber dengan baik dan benar. Dengan demikian dapat disimpulkan bahwa edukasi kepada kader gizi kesehatan se-Kecamatan Mondokan, telah berhasil dapat meningkatkan pengetahuan dan pemahaman peserta dalam upaya pencegahan dan penanggulangan stunting.

Keunggulan dari edukasi bidang gizi kesehatan ini yaitu bahwa topik materi yang diberikan sangat sesuai dengan kebutuhan masyarakat di lokasi penyuluhan dalam pencegahan stunting pada masa balita. Pemerintah Kecamatan Mondokan, Kabupaten Sragen memfasilitasi kegiatan ini dengan baik. Metode edukasi yang digunakan cukup menarik bagi peserta. Dokumentasi kegiatan pengabdian ini berupa foto yang diambil pada saat kegiatan edukasi berlangsung kepada kader di Kecamatan Mondokan, Kabupaten Sragen (Gambar 1 dan Gambar 2). Setiap dokumentasi telah diberi pembahasan yang menjelaskan tentang kegiatan yang dilakukan dalam dokumentasi.

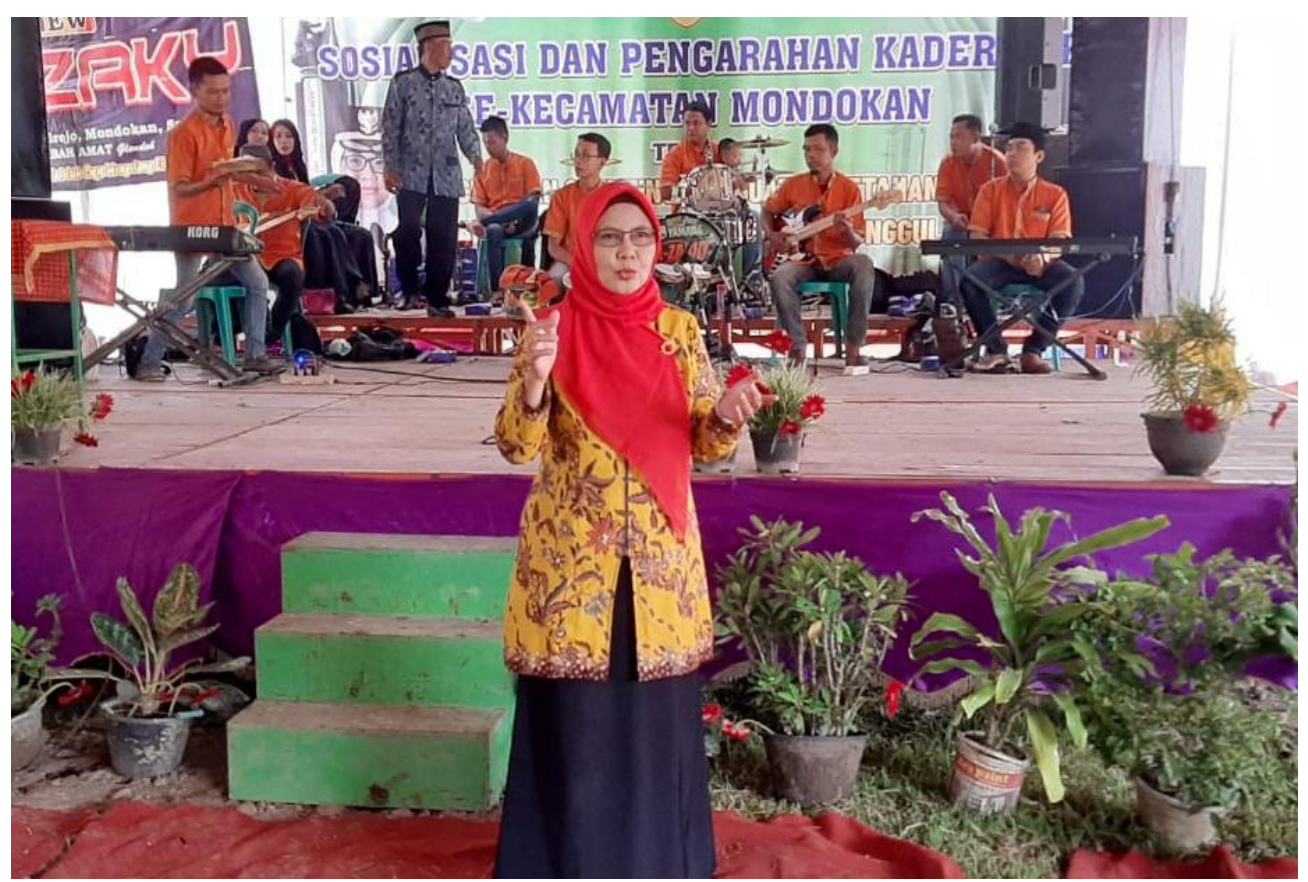

Gambar 1. Penyampaian materi edukasi pencegahan dan penanggulangan stunting dalam forum pengarahan kader se-Kecamatan Mondokan, Kabupaten Sragen 


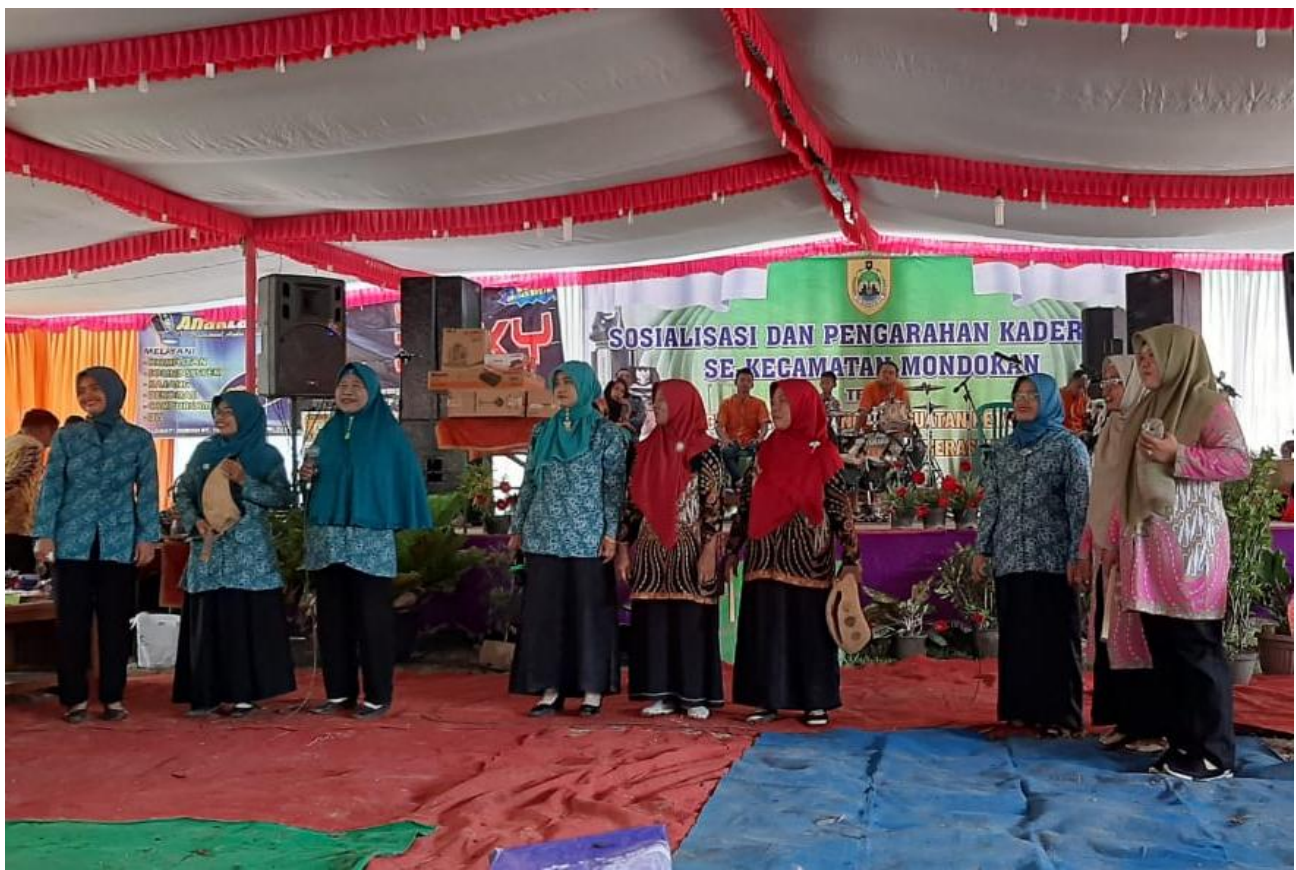

Gambar 2. Penilaian/evaluasi pengetahuan dan pemahanan peserta edukasi melalui "game" berupa cerdas-cermat (satu regu terdiri dari tiga orang kader yang mewakili satu desa)

Pengabdian ini juga mempunyai kelemahan yaitu dalam pelaksanaan tatap muka dengan sasaran edukasi hanya satu kali dengan pemberian materi yang cukup banyak. Oleh karena itu, tim pengabdi berencana pada waktu mendatang untuk menindaklanjuti dengan kegiatan pengabdian masyarakat yang berupa pelatihan dan pendampingan, melihat antusiasme peserta yang tinggi dan karena wilayah Kabupaten Sragen mempunyai angka kejadian stunting yang masih tinggi yaitu $39,7 \%$ (Riskesdas, 2018) sehingga termasuk dalam 100 daerah prioritas penanganan stunting oleh Pemerintah Pusat. Prevalensi tertinggi kasus stunting berada di Kecamatan Mondokan. Dengan adanya kegiatan pengabdian yang berkelanjutan diharapkan dapat tercapai tujuan untuk dapat menurunkan angka kejadian stunting di wilayah tersebut.

\section{KESIMPULAN}

Kegiatan pengabdian ini telah dapat mencapai tujuannya yaitu untuk meningkatkan pengetahuan dan pemahaman para kader gizi kesehatan di wilayah Kecamatan Mondokan tentang pencegahan dan penanggulangan stunting namun demikian kegiatan edukasi ini perlu ditindaklanjuti dengan pelatihan dan pendampingan berkelanjutan, mengingat wilayah kecamatan
Mondokan merupakan salah satu kecamatan yang prevalensi stunting paling tinggi di Kabupaten Sragen. Pemerintah Kecamatan Mondokan telah bekerjasama dengan baik dalam memfasilitasi kegiatan ini sehingga berjalan dengan lancar. Para kader gizi kesehatan sangat antusias dalam mengikuti kegiatan. Dengan adanya keberlanjutan program diharapkan para kader tidak hanya tahu dan paham. Dalam jangka panjang diharapkan para kader mempunyai sikap dan perilaku positif dalam upaya pencegahan dan penanggulangan stunting dalam menjalankan tugasnya sebagai kader di posyandu sehingga mereka dapat memberikan kontribusi yang lebih baik untuk mendukung pemerintah dalam upaya menurunkan prevalensi stunting pada balita.

\section{UCAPAN TERIMA KASIH}

Penulis menyampaikan terima kasih kepada Bapak Camat Mondokan beserta staf yang telah bekerjasama dengan baik dan memfasilitasi untuk terlaksananya kegiatan pengabdian ini dengan lancar. Tak lupa penulis juga berterimakasih kepada para kader PKK se-Kecamatan Mondokan yang telah berpartisipasi aktif dalam mengikuti dan mendukung kegiatan ini, walaupun lokasi kegiatan cukup jauh dari rumah kediaman sebagian besar kader. 


\section{DAFTAR PUSTAKA}

Kemenkes. (2014). Modul Pelatihan Konseling dan Pemberian Makan Bayi dan Anak. Jakarta: Direktorat Jederal Bina Gizi dan KIA. Tersedia dari http://www.mca-indonesia.go. id/assets/uploads/media/pdf/Panduan-Penyele nggaraan-PMBA.pdf

Meadow, R., \& Newell, S. (2005). Lecture Notes Pediatrika Edisi Ketujuh. Jakarta. Erlangga Medical Series.

Naidoo, J., \& Wills, J. (2008). Health Promotion Foundation For Practices. Bailliere Tindall: London.

Pemerintah Kabupaten Sragen. (2019). Bupati Yuni : Presentase Stunting (Anak Pendek) meningkat Akibat Pernikahan Dini. Tersedia dari http://sragenkab.go.id/berita-1870.html

Ramli, Agho, K. E., Inder, K. J., Bowe, S. J., Jacobs, J., \& Dibley, M. J. (2009). Prevalence and Risk Factors for Stunting and Severe Stunting Among Under-fives in North Maluku Province of Indonesia. BMC Pediatrics, 9, 64. http://doi.org/10.1186/1471-2431-9-64

RISKESDAS. (2013). Riset Kesehatan Dasar; RISKESDAS 2013. Jakarta: Badan Penelitian dan Pengembangan Kesehatan, Kementerian Kesehatan RI. Tersedia dari http://labdata.lit bang.kemkes.go.id/images/download/laporan/ RKD/2013/Laporan_riskesdas_2013_final.pd $\mathrm{f}$

Simondon, K. B., Simondon, F., Costes, R., Delaunay, V., \& Diallo, A. (2001). Breastfeeding is associated with improved growth in length, but not weight, in rural Senegalese toddlers, The American Journal of Clinical Nutrition, 73(5), 959-967. https://doi.org/10 $.1093 / \mathrm{ajcn} / 73.5 .959$

Soetjiningsih. (2002). Buku Ajar Tumbuh Kembang Anak. Jakarta: EGC.

Supariasa, N. D. I., Bakri, B., \& Fajar, I. (2001). Penilaian Status Gizi. Jakarta : Penerbit Buku Kedokteran EGC. Tersedia dari http://bppsd mk.kemkes.go.id/pusdiksdmk/wp-content/up loads/2017/11/PENILAIAN-STATUS-GIZIFINAL-SC.pdf

UNICEF. (2010). Improving Exclusive Breast feeding Practices. UNICEF C4D Orientation Webinar Series. Tersedia dari https://www. unicef.org/nutrition/files/C4D_for_breastfeedi ng_webinar_presentation.pdf

Waterlow, J. C., \& Schurch, B. (1994). Causes and mechanismof linear growth retardation. Eur $J$ Clin Nutr, 48(Suppl 1), S1-S4. https://www.ncbi.nlm.nih.gov/pubmed/80050 78

WHO. (2006). WHO Child Growth Standards, Length/Height For-Age, weight-For-Age, Weight-For-Length, Weight-For-Height and Body Mass Index-For-Age : Methods and Development. Geneva: Department of Nutrition for Health and Development. Tersedia dari https://www.who.int/childgro wth/standards/technical_report/en/

WHO. (2013). Childhood Stunting: Context, Causes and Consequences. WHO Conceptual framework. Tersedia dari https://www.who. int/nutrition/events/2013_ChildhoodStunting colloquium_14Oct_ConceptualFramework_c olour.pdf 